\title{
Participatory Management Process in Natural Resource Management (NRM) by Women Groups
}

\author{
Waheeda Munawer ${ }^{1}$, S. Senthil Vinayagam² and D. Raghunatha Reddy ${ }^{3}$
}

\begin{abstract}
Conserving the natural resources results in improved agricultural productivity which is a key driver for poverty reduction in rural areas. To empower the women and to enhance their socio-economic status for better livelihoods, Self-Help Groups (SHG) were formed by both the Government Organizations (GO) and Non-Government Organizations (NGO). They facilitated the participation of women through various means in Natural Resource Management (NRM) activities. To find out the distribution of the women groups in different stages of NRM activities and to analyze the influence of profile, supportive, structural and functional characteristics on participatory management in NRM activities, an ex-post facto study was conducted in Telangana, Coastal Andhra and Rayalaseema regions among 240 SHGs. The study revealed that majority of the women respondents had medium level of 'total participatory management' followed by high level and low level.
\end{abstract}

Keywords: Women; Self Help Group; Participatory management; Natural Resource Mangement; Telangana; Andhra Pradesh

\section{INTRODUCTION}

Natural resource management and poverty alleviation are being considered as two-sides of the same coin. Conserving the natural resourceresults in improved agricultural productivity which is a key driver for poverty reduction in rural areas. Agricultural growth generates the income and livelihood for the poorest of the poor. The experiences gained in watershed management programmes proved that the livelihood of the rural people depends on agriculture which links with watersheds and

natural resources importance. The challenges in sustainable Natural Resources Management (NRM) are to be addressed by involving participation of communities who are living in close association with these natural resources.

In general, participation of women in groups plays a vital role in Natural Resources Management (NRM) and sustainable livelihood development. To empower the women and to enhance their socio-economic status for better livelihoods, Self-Help groups

1. Ph.D Scholar, National Institute of Agrl. Extension Management, Rajendra Nagar, Hyderabad - 500 030. 2. Principal Scientist, ICAR-National Academy of Agrl. Extension Management, Rajendra Nagar, Hyderabad - 500 030 and 3. Professor, Jawaharlal Nehru Technology University Hyderabad, Kukatpally, Hyderabad - 500085. 
(SHG) were formed by both the Government Organizations (GO) and Non-Government Organizations (NGO). There is a need to assess the involvement of GOs and NGOs in women empowerment for the sustainable livelihood development among poor families in the rural societies. Many approaches are employed to involve women in the planning, implementation, execution and monitoring of natural resources. Many research programmes have been initiated to implement and enhance this participatory process management. The GOs and NGOs also facilitated the participation of women through various means. In this paper, an attempt has been made to find out the distribution of the women groups in different stages of NRM activities and to analyze the influence of profile, supportive, structural and functional characteristics on participatory management in NRM activities.

\section{METHODOLOGY}

An ex-post facto research design was adopted for the study. All the three regions of united Andhra Pradesh (Telangana, Coastal Andhra and Rayalaseema) were selected for the study and from each region one district was selected based more number of women groups (SHGs). A total of 240 SHGs (120 from Government promoted groups and 120 from Non-Government promoted groups) and 60 GO and NGO officials were selected from three districts who constituted the sample. A pre-tested interview schedule was used for data collection. The obtained data was analyzed and tested with the help of standard statistical tools.

\section{FINDINGS AND DISCUSSION}

Participatory management is operationally defined as the involvement of women members of different women groups (SHGs) in different development activities by way of interaction with Natural Resource Management officials, expressing their views and sharing their responsibilities during pre-watershed stage, planning stage, implementation stage, maintenance stage and evaluation stage components. Participatory management was quantified with the scale consisting 30 statements developed for the study based on the lines of scale construction procedure adopted by Reddy (1992) with slight modification.

The distribution of respondents according to their involvement in different stages of NRM activities (Table 1 ) revealed that majority (38.75\%) of the women in groups were involved in 'high level' during pre-watershed stage. This may be due to their involvement and interest towards establishment of watershed activities in their locality and to establish some economic activity for their livelihood. $42.08 \%$ of the women in groups were involved in planning stage at 'medium level'. This may be due to minimum availability of experts in the groups to involve in planning process. Majority of the respondents were at 'low level' at implementation stage (40.83\%), maintenance stage (37.50\%) and at evaluation stage $(52.50 \%)$. This may be due to less income from watershed activities during planning stage, more expenditure and delay of release of amount from funding agency for maintenance purpose and involvement of 
group leader only for evaluation stage.

Table 1.

Distribution of Respondents According to their Involvement in Different Stages of NRM Activities

$(n=240)$

\begin{tabular}{|c|c|c|c|}
\hline \multirow{2}{*}{$\begin{array}{r}\text { SI. } \\
\text { No. } \\
1\end{array}$} & \multirow{2}{*}{$\begin{array}{c}\text { Stages } \\
\text { Pre-watershed stage }\end{array}$} & \multicolumn{2}{|c|}{$\begin{array}{l}\text { No. of } \\
\text { respondents }\end{array}$} \\
\hline & & $\mathrm{F}$ & $\%$ \\
\hline & $\operatorname{Low}(15-16)$ & 61 & 25.42 \\
\hline & Medium(17-18) & 86 & 35.83 \\
\hline & High (19-20) & 93 & 38.75 \\
\hline & Total & 240 & 100 \\
\hline \multirow[t]{5}{*}{2} & Planning stage & F & $\%$ \\
\hline & Low (9-10) & 55 & 22.92 \\
\hline & Medium (11-12) & 101 & 42.08 \\
\hline & High (13-14) & 84 & 35.00 \\
\hline & Total & 240 & 100 \\
\hline \multirow[t]{5}{*}{3} & $\begin{array}{l}\text { Implementation } \\
\text { stage }\end{array}$ & $F$ & $\%$ \\
\hline & $\operatorname{Low}(25-26)$ & 98 & 40.83 \\
\hline & Medium(27-28) & 76 & 31.67 \\
\hline & High (29-30) & 66 & 27.50 \\
\hline & Total & 240 & 100 \\
\hline \multirow[t]{5}{*}{4} & Maintenance stage & $\mathbf{F}$ & $\%$ \\
\hline & $\operatorname{Low}(7-8)$ & 90 & 37.50 \\
\hline & Medium(9-10) & 83 & 34.58 \\
\hline & High (11-12) & 67 & 27.92 \\
\hline & Total & 240 & 100 \\
\hline
\end{tabular}

\begin{tabular}{|c|l|l|l|}
\hline $\begin{array}{c}\text { Sl. } \\
\text { No. }\end{array}$ & \multicolumn{1}{|c|}{ Stages } & \multicolumn{2}{c|}{$\begin{array}{c}\text { No. of } \\
\text { respondents }\end{array}$} \\
\hline 5 & Evaluation stage & F & $\%$ \\
\cline { 2 - 4 } & Low(7-8) & 126 & 52.50 \\
\cline { 2 - 4 } & Medium(9-10) & 64 & 26.67 \\
\hline \multirow{4}{*}{6} & High (11-12) & 50 & 20.83 \\
\cline { 2 - 4 } & Total & 240 & 100 \\
\hline \multirow{4}{*}{ Total Participatory } & Management & $\%$ & F \\
\cline { 2 - 4 } & Low(63-71) & 58 & 24.17 \\
\cline { 2 - 4 } & Medium(72-80) & 119 & 59.58 \\
\cline { 2 - 4 } & High (81-89) & 63 & 26.25 \\
\hline
\end{tabular}

As regards total participatory management, it could be inferred that majority of the respondents (59.58\%) had medium level of participation in watershed management activities under NRM. The reason for such trend could be medium level of awareness on NRM activities both by government and nongovernment organizations.

Relationship of Profile, Supportive, Structural and Functional Characteristics of Women with their Participatory Management in Groups

In order to study the nature of relationship between the profile, supportive, structural and functional characteristics and dependent variables, correlation coefficients $(r)$ were computed and values are presented. 
Participatory Management Process in Natural Resource Management (NRM) by Women Groups

Table 2.

Correlation Analysis of Profile, Supportive, Structural and Functional Characteristics with Participatory Management

\begin{tabular}{|c|c|c|c|c|}
\hline \multirow{2}{*}{$\begin{array}{l}\text { Sl. } \\
\text { No. }\end{array}$} & \multirow{2}{*}{ Independent variable } & \multicolumn{3}{|c|}{$\begin{array}{l}\text { Correlation coefficient }(r) \text { values- Participatory } \\
\text { Management }\end{array}$} \\
\hline & & $\begin{array}{l}\text { Government } \\
(n=120)\end{array}$ & $\begin{array}{l}\text { NGO } \\
(n=120)\end{array}$ & $\begin{array}{c}\text { Total } \\
(n=240)\end{array}$ \\
\hline 1. & Age & -0.163 & 0.083 & -0.018 \\
\hline 2. & Family Type & 0.033 & 0.118 & 0.075 \\
\hline 3. & Family Size & $0.177^{*}$ & $0.221^{*}$ & $0.199^{* *}$ \\
\hline 4. & Caste & 0.047 & 0.086 & 0.119 \\
\hline 5. & Education/ literacy level & $0.351^{* *}$ & $0.261^{*}$ & $0.278^{* *}$ \\
\hline 6. & Farming Experience & $0.041^{* *}$ & $0.312^{* *}$ & $0.187^{* *}$ \\
\hline 7. & Occupation & 0.081 & 0.089 & 0.108 \\
\hline 8. & Annual income & 0.089 & 0.072 & $0.108^{* *}$ \\
\hline 9. & Awareness on NRM activities & $0.194^{*}$ & $0.345^{* *}$ & $0.162^{*}$ \\
\hline 10. & Land Holding & 0.111 & 0.000 & 0.054 \\
\hline 11. & Capacity Building in NRM & 0.077 & 0.089 & 0.104 \\
\hline 12. & Extension Contact & $0.255^{* *}$ & $0.289^{* *}$ & $0.328^{* *}$ \\
\hline 13. & Socio-Political Participation & $0.392^{* *}$ & $0.169^{*}$ & $0.349^{* *}$ \\
\hline 14. & Mass Media Exposure & $0.365^{* *}$ & $0.338^{* *}$ & $0.423^{* *}$ \\
\hline 15. & Information seeking Behavior & 0.177 & 0.119 & 0.089 \\
\hline 16. & Decision Making Ability & 0.095 & 0.103 & 0.065 \\
\hline 17. & Working Age of the group & 0.074 & $0.185^{*}$ & 0.096 \\
\hline 18. & Group Size & $0.211^{*}$ & $0.342^{* *}$ & $0.369^{* *}$ \\
\hline 19. & Supportive Environment & $0.465^{* *}$ & $0.262^{* *}$ & $0.178^{*}$ \\
\hline 20. & Nature of economic activity & $0.194^{*}$ & $0.227^{*}$ & $0.152^{*}$ \\
\hline 21. & Frequency of group meeting & 0.141 & 0.149 & 0.103 \\
\hline 22. & Group Process & $0.458^{* *}$ & 0.079 & $0.280^{* *}$ \\
\hline 23. & Group Sustainability & $0.412^{* *}$ & $0.208^{*}$ & $0.272^{* *}$ \\
\hline 24. & Group norms & $0.450^{* *}$ & $0.353^{* *}$ & $0.347^{* *}$ \\
\hline 25. & Group Leadership & $0.714^{* *}$ & $0.431^{* *}$ & $0.597^{* *}$ \\
\hline 26. & Team Work & $0.372^{* *}$ & $0.265^{* *}$ & $0.303^{* *}$ \\
\hline 27. & Group Achievement & $0.442^{* *}$ & $0.214^{*}$ & $0.309^{* *}$ \\
\hline
\end{tabular}

${ }^{*}$ : Significant at 5 per cent level 
It could be inferred from Table 2 that the profile characteristics such as family size, education, farming experience and annual income, supportive characteristics such as awareness on NRM, extension contact, socio-political participation and mass media exposure, structural characteristics such as group size, supportive environment and nature of economic activity, functional characteristics such as group process, group sustainability, group norms, group leadership, team work and group achievement had positive and significant relationship with participatory management.

It could be also inferred from the results that the functional characteristics of the women in groups had more significant and positive relationship with participatory management than profile, supportive and structural characteristics. Hence strengthening the capacity of women in groups through developing leadership, group processing, team work, group achievement and formulating group norms will help in developing more participatory approach towards watershed management under NRM activities.

Influence of Profile, Supportive, Structural and Functional Characteristics on Participatory Management

Multiple linear regression analysis was carried out to determine the influence of the profile, supportive, structural and functional characteristics in predicting the participatory management of women groups towards participatory approach in NRM activities.

Table 3.

Influence of Profile, Supportive, Structural and Functional Characteristics on Participatory Management

\begin{tabular}{|c|l|c|c|c|}
\hline SI.No. & \multicolumn{1}{|c|}{ Independent variable } & $\begin{array}{c}\text { Regression } \\
\text { Coefficient }\end{array}$ & $\begin{array}{c}\text { Standard } \\
\text { Error }\end{array}$ & 't' Value \\
\hline 1. & Age & 0.07290 & 0.04320 & 1.69 \\
\hline 2. & Family Type & 2.14018 & 0.72787 & $2.94^{* *}$ \\
\hline 3. & Family Size & 0.45932 & 0.17844 & $2.57^{*}$ \\
\hline 4. & Caste (ST, SC, BC, OC) & 0.48953 & 0.31026 & 1.58 \\
\hline 5. & Education/ literacy level & -0.59833 & 0.28911 & $2.07^{*}$ \\
\hline 6. & Farming Experience & 0.03765 & 0.03910 & 0.96 \\
\hline 7. & Occupation & -0.07011 & 0.16534 & 0.42 \\
\hline 8. & Annual income & 0.00001792 & 0.00000710 & $2.52^{*}$ \\
\hline 9. & Awareness on NRM activities & -0.01457 & 0.09740 & 0.15 \\
\hline 10. & Land Holding & 0.05470 & 0.11773 & 0.46 \\
\hline 11. & Capacity Building in NRM & 1.47517 & 0.78467 & 1.88 \\
\hline 12. & Extension Contact & 0.20130 & 0.26176 & 0.77 \\
\hline
\end{tabular}


Participatory Management Process in Natural Resource Management (NRM) by Women Groups

\begin{tabular}{|l|l|c|c|c|}
\hline 13. & Socio-Political Participation & -0.16353 & 0.12836 & 1.27 \\
\hline 14. & Mass Media Exposure & 0.46389 & 0.21385 & $2.17^{*}$ \\
\hline 15. & Information seeking Behavior & -0.05250 & 0.08298 & 0.63 \\
\hline 16. & Decision Making Ability & -0.00820 & 0.05880 & 0.14 \\
\hline 17. & Working Age of the group & -0.02616 & 0.07842 & 0.33 \\
\hline 18. & Group Size & 0.33584 & 0.16607 & $2.02^{*}$ \\
\hline 19. & Supportive Environment & -0.21825 & 0.06048 & $3.61^{* *}$ \\
\hline 20. & Nature of economic activity & -2.13167 & 0.72987 & $2.92^{* *}$ \\
\hline 21. & Frequency of group meeting & 0.01092 & 0.31627 & 0.03 \\
\hline 22. & Group Process & -0.06072 & 0.04563 & 1.33 \\
\hline 23. & Group Sustainability & 0.54997 & 0.24175 & $2.27^{*}$ \\
\hline 24. & Group norms & 0.22056 & 0.18818 & 1.17 \\
\hline 25. & Group Leadership & 0.70222 & 0.10747 & $6.53^{* *}$ \\
\hline 26. & Team Work & 0.20323 & 0.08233 & $2.47^{* *}$ \\
\hline 27. & Group Achievement & 0.28102 & 0.09692 & $2.90^{* *}$ \\
\hline
\end{tabular}

* : Significant at 5 per cent level

\begin{tabular}{|c|c|c|}
\hline F value & $\mathrm{R}^{2}$ & Intercept \\
\hline 11.39 & 0.5920 & 52.593 \\
\hline
\end{tabular}

On the whole it is observed that in both Government and NGO-promoted women groups the selected independent variables on participatory management together explained the variation to the extent of 59.2 per cent (Table 3). The unexplained variation to the extent of 40.8 per cent may be attributed by the variables which were not included in the study. The F value 11.39 was found to be showing significant variation. Family type, supportive environment, nature of economic activity, group leadership, team work and group achievement were most visible and tangible aspect that made variation in the participatory management of the respondents at 1 per cent level of significance while family size, education, annual income, mass media exposure, group size and group sustainability contributed significantly to brought up the variation in the participatory management at 5 per cent level of significance.

\section{CONCLUSION}

Women are highly linked with different activities both farm and non-farm, by using appropriate natural / agricultural resources and / or their product. They also receive support from GOs and NGOs through various schemes and programmes which encourage their participation. This paper revealed that majority of the respondents of the 
women had medium level of total participatory management followed by high level and low level. The reason for such a trend could be the medium level of awareness on NRM activities both by government and non-government organizations. Further, the capacity building programmes offered by promoting agencies are to be informed to the women groups well in advance. The results suggests attracting young women by creating more avenues and enterprises based on NRM activities and to develop strategies for promotion of marketing support for the women groups to market their produce for ensuring sustainable livelihood.

\section{REFERENCES}

Reddy,C.(1992). A study to identify the constraints in adoption of improved mango production technology in Khammam district of Andhra Pradesh. Unpublished MSc.(Ag.) Thesis, APAU, Hyderabad. 